\title{
Acetate kinase from Clostridium acetobutylicum : a highly specific enzyme that is actively transcribed during acidogenesis and solventogenesis
}

\author{
Klaus Winzer, $†$ Karin Lorenz and Peter Dürre
}

Angewandte

Mikrobiologie und

Mykologie, Universitat

Ulm, D-89069 Ulm,

Germany
Author for correspondence: Peter Dürre. Tel: +49731 502 2710. Fax: +49731502 2719.
e-mail: peter.duerre@biologie.uni-ulm.de
Acetate kinase (ATP:phosphotransferase, EC 2.7.2.1) has been purified 294fold from acid-producing cells of Clostridium acetobutylicum DSM 1731 to a specific activity of $1087 \mathrm{U} \mathrm{mg}^{-1}$ (ADP-forming direction). The dimeric enzyme consisted of subunits with a molecular mass of $43 \mathrm{kDa}$. The molecular mass of the native acetate kinase was in the range $87-94 \mathrm{kDa}$ as judged by gel filtration and native gel electrophoresis. The enzyme showed high specificity for the substrates acetate and ATP, and maximal activity was obtained with $\mathrm{Mn}^{2+}$ as divalent cation. The presence of mercury compounds such as $\mathrm{HgCl}_{2}$ and p-hydroxymercuribenzoate resulted in an essential loss of activity. The apparent $K_{m}$ values for acetate, Mg-ATP, acetyl phosphate, and Mg-ADP were $73,0.37,0.58$ and $0.71 \mathrm{mM}$. An activity-staining procedure for detection of acetate kinase in crude cell extracts after separation on native polyacrylamide gels was developed. A DNA fragment encoding 246 bp of the acetate kinase gene of C. acetobutylicum DSM 792 was cloned by a PCR-based approach. Northern blot analysis revealed transcription of the gene under acid- and solvent-producing conditions with no significant differences at the level of transcription.

Keywords: acetate kinase, ack gene, acidogenesis, butyrate kinase, Clostridium acetobutylicum

\section{INTRODUCTION}

Clostridium acetobutylicum, a Gram-positive, obligately anaerobic, spore-forming bacterium typically shows a biphasic fermentation pattern. During growth in batch culture, the organism first forms acids such as acetate and butyrate, but switches to the production of solvents shortly before entering the stationary phase (for reviews, see Jones \& Woods, 1986; Dürre \& Bahl, 1996). Acetate and butyrate are synthesized from the respective acylCoA esters catalysed by phosphotransacetylase and acetate kinase (ATP: phosphotransferase, EC 2.7.2.1) on the one hand and phosphotransbutyrylase and butyrate kinase on the other. These reactions are most important for energy conservation in the acid-producing

†Present address: Department of Pharmaceutical Sciences, School of Pharmacy, University of Nottingham, University Park, Nottingham NG7 2RD, UK.

Abbreviations: NBT, nitro blue tetrazolium; PMS, phenazinemethosulfate. stage of fermentation. So far, only butyrate kinase and phosphotransbutyrylase have been purified and characterized (Hartmanis, 1987; Wiesenborn et al., 1989). The purified butyrate kinase also shows a low reaction rate with acetate as substrate, but the high level of acetate and butyrate kinase activities in crude extracts (Andersch et al., 1983; Hartmanis \& Gatenbeck, 1984) demonstrates that both activities are represented by different enzymes. At the onset of solvent formation the cells take up the previously produced acids and form acetone and butanol. A CoA transferase seems to be responsible for the reactivation of acetate and butyrate (Andersch et al., 1983; Hartmanis et al., 1984), but the involvement of additional systems has not been ruled out. Butyryl-CoA formation is also possible by the reversible reactions of butyrate kinase and phosphotransbutyrylase (Hüsemann \& Papoutsakis, 1989). This report describes the purification and properties of the acetate kinase from C. acetobutylicum DSM 1731 and the transcription of the respective gene during acid and solvent fermentation. 


\section{METHODS}

Strains, plasmids and growth conditions. C. acetobutylicum DSM 792 and DSM 1731 (Deutsche Sammlung von Mikroorganismen und Zellkulturen) were used as a source of genomic DNA for Southern blot hybridizations and PCR amplifications, of RNA, and of the enzyme acetate kinase. Escherichia coli JM109 was used as a host in cloning experiments and pUC18 (Yanisch-Perron et al., 1985) as a vector.

In batch culture, C. acetobutylicum was grown under strictly anaerobic conditions at $37^{\circ} \mathrm{C}$ in clostridial basal medium (O'Brien \& Morris, 1971). Continuous culture experiments (1 1 culture volume) were performed as described by Bahl et al. (1982). For maintenance of acid formation the $\mathrm{pH}$ was constantly titrated to 6.3 with $\mathrm{KOH}$. Solvent formation was induced by turning off the $\mathrm{pH}$ control. Due to the continued production of acids the $\mathrm{pH}$ dropped to a value of $4 \cdot 3$, at which point the control was turned on again.

E. coli was cultivated at $37^{\circ} \mathrm{C}$ in LB medium (Sambrook et al., 1989) supplemented with $50 \mu \mathrm{g}$ ampicillin $\mathrm{ml}^{-1}, 50 \mu \mathrm{g}$ IPTG $\mathrm{ml}^{-1}$ or $40 \mu \mathrm{g} \mathrm{X}-\mathrm{Gal} \mathrm{ml} \mathrm{m}^{-1}$, when required.

Preparation of crude extracts from C. acetobutylicum DSM 1731. Continuous cultures of C. acetobutylicum DSM 1731 were grown under acid-producing conditions. Cells were harvested by centrifugation of $500 \mathrm{ml}$ cell suspension taken daily from the continuous culture, and stored at $-70^{\circ} \mathrm{C}$. Crude extracts were prepared by suspending the cells in imidazole buffer ( $20 \mathrm{mM}$ imidazole, $8.7 \%$ glycerol, v/v, $\mathrm{pH}$ 6.5) followed by three passages through a French press at $140 \mathrm{MPa}$ (American Instrument) and centrifugation $(20 \mathrm{~min}$, $30000 \mathrm{~g}$ ) to remove cell debris.

Chromatography. Anion-exchange and affinity chromatography were carried out at $8^{\circ} \mathrm{C}$, and hydroxylapatite chromatography was at room temperature.

Anion-exchange chromatography: Crude extracts $(25 \mathrm{ml}$, $400-600 \mathrm{mg}$ protein) were applied to C $26 / 40$ columns (Pharmacia Biotech Europe) containing $50 \mathrm{ml}$ Q-Sepharose FastFlow (Pharmacia) which was equilibrated with imidazole buffer. The enzyme was eluted by a $\mathrm{NaCl}$ gradient from $0-500 \mathrm{mM}$ (in imidazole buffer; $2 \mathrm{l}$ ) at a flow rate of $1 \mathrm{ml}$ $\mathrm{min}^{-1}$. Fractions with high activity were pooled and concentrated using Diaflo chambers and PM 10 membranes (Amicon).

Affinity chromatography: About $10 \mathrm{mg}$ protein (in $2 \mathrm{ml}$ ) was loaded onto a $C 10 / 20$ column containing $8 \mathrm{ml}$ Procion Blue HE-3B (Pharmacia) equilibrated with imidazole buffer. The column was washed with $40 \mathrm{ml}$ of the same buffer, and the enzyme was eluted by an ATP gradient $(0-1 \mathrm{mM}$ ATP in imidazole buffer; $80 \mathrm{ml}$ ) at a maximal flow rate of $10 \mathrm{ml} \mathrm{h}^{-1}$. The fractions with high acetate kinase activity were pooled and shifted into $5 \mathrm{mM} \mathrm{KP}$ buffer (see below) by gel filtration on PD 10 columns (Pharmacia).

Hydroxylapatite chromatography: KP buffers of different concentrations were prepared by diluting $1 \mathrm{M} \mathrm{KP}$ buffer $\left(\mathrm{K}_{2} \mathrm{HPO}_{4} / \mathrm{KH}_{2} \mathrm{PO}_{4}, \mathrm{pH} 7 \cdot 5\right)$ with boiled $\mathrm{H}_{2} \mathrm{O}$. Hydroxylapatite ( $3 \mathrm{~g}$ ) (DNA grade Bio-Gel HTP; Bio-Rad) pre-swollen in $5 \mathrm{mM} \mathrm{KP}$ buffer was transferred into empty PD 10 columns (bed volume about $5 \mathrm{ml}$ ). After loading the sample and washing with $20 \mathrm{ml}$ of 5 and $50 \mathrm{mM} \mathrm{KP}$ buffer, respectively, the enzyme was eluted with $60 \mathrm{mM} \mathrm{KP}$ buffer. The flow rate was $0 \cdot 1-0.3 \mathrm{ml} \mathrm{min}^{-1}$.

Enzyme assays. Acetate kinase activity was assayed in both directions, using enzyme-linked assays for the detection of (i) ATP and (ii) ADP formation, and the hydroxamate assay (iii) for detecting acetyl phosphate formation. All assays were performed at $30^{\circ} \mathrm{C}$ and $1 \mathrm{U}$ was defined as the amount of enzyme required to catalyse the formation of $1 \mu \mathrm{mol}$ ADP $\min ^{-1}$ (or ATP and acetyl phosphate, respectively) under standard assay conditions. Deviations from the standard systems are noted in the respective context. Butyrate kinase activity was assayed by replacing potassium acetate with potassium butyrate in methods (ii) and (iii).

Method (i): The standard assay mixture $(0.4 \mathrm{ml})$ contained: $100 \mathrm{mM}$ imidazole $/ \mathrm{HCl}$ buffer (pH 7.3), $20 \mathrm{mM}$ glucose, $10 \mathrm{mM}$ ADP, $30 \mathrm{mM} \mathrm{MgCl}_{2}, 3.2 \mathrm{mM}$ NADP, 40 and $20 \mu \mathrm{g}$ hexokinase and glucose-6-phosphate dehydrogenase (Boehringer Mannheim), respectively (final concentrations). Acetate-kinase-containing samples were added, and the reaction was started by the addition of acetyl phosphate (final concentration $50 \mathrm{mM}$ ). NADPH formation was followed at $365 \mathrm{~nm}$.

Method (ii): A standard reaction mixture $(0.5 \mathrm{ml})$ contained (final concentrations): $80 \mathrm{mM}$ imidazole/ $\mathrm{HCl}$ buffer $(\mathrm{pH} \mathrm{7 \cdot 3)}$, $1.5 \mathrm{mM}$ phosphoenolpyruvate, $10 \mathrm{mM}$ ATP, $20 \mathrm{mM} \mathrm{MgCl}$, $0.56 \mathrm{mM}$ NADH, $40 \mu \mathrm{g}$ pyruvate kinase, $20 \mu \mathrm{g}$ lactate dehydrogenase, $4 \mathrm{U}$ myokinase (all enzymes from Boehringer Mannheim). The reactions were started with potassium acetate $(320 \mathrm{mM})$ after addition of acetate-kinase-containing samples. NADH oxidation was followed at $365 \mathrm{~nm}$.

Method (iii): The hydroxamate assay was based on the protocol of Rose et al. (1954). For standard applications the reaction mixture $(0.3 \mathrm{ml})$ contained the following components (final concentrations): $200 \mathrm{mM}$ Tris/ $\mathrm{HCl}$ (pH 7.4), $10 \mathrm{mM}$ ATP, $267 \mathrm{mM}$ potassium acetate, $11 \mathrm{mM} \mathrm{MgCl}$ and $6 \%(\mathrm{w} / \mathrm{v})$ hydroxylamine hydrochloride (neutralized with $\mathrm{KOH}$ before addition). The reaction was started by acetate-kinase-containing solutions and stopped after 2-20 min by the addition of $0.3 \mathrm{ml} 10 \%(\mathrm{w} / \mathrm{v})$ trichloroacetic acid. Colour was developed by addition of $0.3 \mathrm{ml} 2.5 \%$ (w/v) $\mathrm{FeCl}_{3}$ in $2.0 \mathrm{M} \mathrm{HCl}$. After vigorous agitation and centrifugation to remove protein precipitates, absorbance of ferric chloride-hydroxamide acid complex was measured at $540 \mathrm{~nm}$ (Zeiss PM4 and Milton Roy Spectronic 601).

Specific staining of active acetate kinase after electrophoretic separation in native polyacrylamide gels was achieved by coupling the acetate kinase activity with hexokinase and glucose-6-phosphate dehydogenase reactions as described for the coupled enzymic assay (i) and the reduction of nitro blue tetrazolium salt (NBT) via phenazinemethosulfate (PMS) by the resulting NADPH. Protein bands representing acetate kinase were identified by a deep purple precipitation of reduced NBT. After electrophoresis the gel was placed on a glass plate and covered with two sheets of Whatman paper soaked with staining solution. The paper sheets were placed in close contact to the surface of the gel without any air bubbles and covered with a second glass plate. Colour was developed during incubation at $37^{\circ} \mathrm{C}$ for $5-30 \mathrm{~min}$. The stained paper sheets could be stored at $-20^{\circ} \mathrm{C}$, and polyacrylamide gels could be subjected to silver staining without marked loss of sensitivity. The staining solution contained the following components (final concentrations): $40 \mathrm{mM}$ imidazole/ $\mathrm{HCl}$ buffer ( $\mathrm{pH} 7 \cdot 3$ ), $20 \mathrm{mM}$ glucose, $4 \mathrm{mM} \mathrm{ADP}, 10 \mathrm{mM} \mathrm{MgCl}$, $1.3 \mathrm{mM}$ NADP, $10 \mathrm{mM}$ acetyl phosphate, $0.3 \mathrm{mg}$ hexokinase, $0.15 \mathrm{mg}$ glucose- 6 -phosphate dehydrogenase, $0.5 \mathrm{mg} \mathrm{PMS}$ and $1.35 \mathrm{mg}$ NBT. PMS and NBT were added immediately before use.

Electrophoresis and molecular mass estimation. PAGE was performed using the Laemmli buffer system (Laemmli, 1970). Under denaturing conditions (in presence of $1 \%, w / v, S D S$ ), $10 \%(\mathrm{w} / \mathrm{v})$ polyacrylamide gels were used to estimate 
molecular mass and purity of acetate kinase subunits. Molecular mass standards (LMW calibration kit; Pharmacia) were lactalbumin $(14.4 \mathrm{kDa})$, trypsin inhibitor $(20.1 \mathrm{kDa})$, carbonic anhydrase $(30 \mathrm{kDa})$, ovalbumin $(43 \mathrm{kDa}), \mathrm{BSA}$ $(67 \mathrm{kDa})$, and phosphorylase $b(94 \mathrm{kDa})$. Non-denaturing linear gradient gels (4-27.5\%, without SDS) were used to estimate the molecular mass of the native enzyme. The following standard was used (HMW Calibration kit; Pharmacia): BSA (67 kDa), lactate dehydrogenase (140 kDa), catalase $(232 \mathrm{kDa})$, ferritin $(440 \mathrm{kDa})$ and thyroglobulin $(660 \mathrm{kDa})$. The gels were silver-stained by the method of Blum et al. (1987).

Gel filtration experiments were performed by FPLC using a Superose 12 column (Pharmacia) equilibrated with $70 \mathrm{mM}$ imidazole/ $\mathrm{HCl}, 10 \mathrm{mM} \mathrm{MgCl}$, $\mathrm{pH} \mathrm{7.0.} \mathrm{In} \mathrm{some} \mathrm{experiments}$ $200 \mathrm{mM} \mathrm{NaCl}$ was added to the equilibration buffer. Molecular mass standards (HMW and LMW gel filtration calibration kit; Pharmacia) were ovalbumin (43 kDa), BSA $(67 \mathrm{kDa})$, aldolase $(158 \mathrm{kDa})$, catalase $(232 \mathrm{kDa})$, ferritin $(440 \mathrm{kDa})$ and thyroglobulin $(660 \mathrm{kDa})$.

Protein determination. Protein determination was performed according to the method of Bradford (1976) using Serva Blue G-250 as dye reagent and BSA (Serva) as standard protein.

Nucleic acid isolation and manipulation. The method of Marmur (1960) as modified by Bertram \& Dürre (1989) was used for the preparation of chromosomal DNA from C. acetobutylicum DSM 792. Plasmid DNA from E. coli was isolated using the Qiagen Midi-Kit. Total RNA of C. acetobutylicum DSM 1731 could be isolated by the hot phenol/chloroform procedure described by Oelmüller $e t$ al. (1990) with the modifications introduced by Gerischer \& Dürre (1992).

DNA was manipulated by standard methods (Sambrook et al., 1989). Restriction enzymes (MBI Fermentas) were used in accordance to the instructions of the manufacturer.

Hybridization. Chromosomal DNA of C. acetobutylicum was digested to completion with the respective restriction enzymes, separated on agarose gels, and transferred to nylon membranes (GeneScreen Plus; Dupont, NEN Research Products) by capillary transfer in $10 \times$ SSC $(1 \times$ SSC is $0.15 \mathrm{M}$ $\mathrm{NaCl}$ plus $15 \mathrm{mM}$ sodium citrate). Prehybridization was performed for $1-2 \mathrm{~h}$ at $60^{\circ} \mathrm{C}$ in $10 \mathrm{ml}$ of the following solution : $0.2 \%(\mathrm{w} / \mathrm{v}$ ) polyvinylpyrrolidone, $0.2 \%(\mathrm{w} / \mathrm{v}) \mathrm{BSA}$, $0.2 \%(\mathrm{w} / \mathrm{v})$ Ficoll $400,0.1 \%(\mathrm{w} / \mathrm{v})$ sodium pyrophosphate, $10 \%(\mathrm{w} / \mathrm{v})$ dextran sulfate, $1 \mathrm{M} \mathrm{NaCl}, 1 \%$ (w/v) SDS, $50 \mathrm{mM}$ Tris $/ \mathrm{HCl}(\mathrm{pH} \mathrm{7.5})$, and $100 \mu \mathrm{g}$ denatured salmon sperm DNA ml-1. Probes were prepared by isolating DNA fragments from agarose gels using the GeneClean kit (Bio101). Labelling was achieved by using a random primer DNAlabelling kit (Gibco-BRL) and $\left[\alpha^{32} \mathrm{P}\right] \mathrm{dATP}$ (Hartmann Analytic). Sephadex G-25 columns (NAP 5 ; Pharmacia) were used to remove free $\left[\alpha^{-32} \mathrm{P}\right] \mathrm{dATP}$ and $0.7-1.9 \times 10^{4} \mathrm{~Bq} \mathrm{ml}^{-1}$ were added to the prehybridization solution. After hybridization at $60{ }^{\circ} \mathrm{C}$ for $12-15 \mathrm{~h}$, the membranes were washed twice in $2 \times$ SSC and once in $2 \times$ SSC plus $1 \%(\mathrm{w} / \mathrm{v})$ SDS for $5 \mathrm{~min}$ at room temperature and subjected to autoradiography.

Total RNA for Northern (RNA) blots was separated in denaturing formaldehyde gels and transferred to nylon membranes (GeneScreen Plus) as described by Sambrook et al. (1989). Fragment sizes were estimated by comparison with an RNA ladder (Gibco-BRL). Hybridization and washing were performed as described above for the Southern blot hybridization procedure, but without salmon sperm DNA in the prehybridization solution.
Oligonucleotides. Synthesis of degenerated oligonucleotides was performed on a Pharmacia Gene Assembler Plus on $0.2 \mu \mathrm{mol}$ capacity columns as recommended by the manufacturer. The oligonucleotides were purified after deprotection by gel filtration on Sephadex G-25 (NAP 5; Pharmacia). The following degenerated oligonucleotides were used in PCR amplifications (nucleotides in wobble positions are indicated in parentheses): AK1, GT(T/A)CA(T/C)GG(T/A)GG(T/A)GA(A/G)AA;AK2, CAT(A/T)GT(T/C)TG(A/G)TG(A/G)AA(A/T)GC; AK3, (G/C)(A/T)(A/G)TT(T/C)TC(T/A)CC(A/T)AT(T/A)CC.

PCR. PCR amplifications were performed in $100 \mu$ l volumes containing the relevant primers $(0.5 \mu \mathrm{M}$ each), deoxyribonucleoside triphosphates $(200 \mu \mathrm{M}$ each $)$, DNA template (about $20 \mathrm{ng}), \mathrm{MgCl}_{2}(2.5 \mathrm{mM})$, and $\mathrm{Taq}$ DNA polymerase $(2.5 \mathrm{U} ; \mathrm{AGS})$ in $1 \times$ reaction buffer $\mathrm{A}(10 \mathrm{mM}$ Tris $/ \mathrm{HCl}$, $16 \mathrm{mM}$ ammonium sulfate, $\mathrm{pH} 8.55)$. The mixture was overlaid with mineral oil. A thermocycler (Trio-Thermoblock; Biometra biomedizinische Analytik) was used under the following conditions : $94^{\circ} \mathrm{C}$ for $30 \mathrm{~s}, 37^{\circ} \mathrm{C}$ for $30 \mathrm{~s}$, and $72{ }^{\circ} \mathrm{C}$ for $1 \mathrm{~min}$ per $1 \mathrm{~kb}$ for 35 cycles.

DNA sequencing. An AutoRead sequencing kit (Pharmacia) was used for non-radioactive sequencing. The dideoxyterminated fragments were separated on $6 \%$ polyacrylamide gels (0.5 mm thick; $20 \mathrm{~cm}$ separation distance) with an ALF DNA Sequencer (Pharmacia) using $0.6 \times \mathrm{TBE}(1 \times \mathrm{TBE}$ is $100 \mathrm{mM}$ Tris, $83 \mathrm{mM}$ boric acid, $1 \mathrm{mM}$ EDTA) at $38 \mathrm{~mA}$, $50^{\circ} \mathrm{C}$ gel temperature, and 2 or $3 \mathrm{~W}$ laser power. A commercial solution (SequaGel XR; National Diagnostics) was used for preparation of polyacrylamide gels.

Computer programs. DNA sequences were analysed using the DNA Strider (Marck 1988) and GeneWorks (IntelliGenetics) programs on a Macintosh IIsi computer (Apple). Sequence comparisons were done by using the GCG program package (Genetics Computer Group sequence analysis software package, version 6.2; Devereux et al., 1984) on a VAX 9000 computer.

\section{RESULTS AND DISCUSSION}

\section{Enzyme purification and characterization}

Acetate kinase was purified from cell extracts of acidproducing C. acetobutylicum DSM 1731 by the steps shown in Table 1. Butyrate and acetate kinase activities could be separated almost completely by anionexchange chromatography on Q-Sepharose FastFlow using a gradient of slightly increasing $\mathrm{NaCl}$ concentrations (Fig. 1). The enzymes were eluted at $\mathrm{NaCl}$ concentrations of 125 and $150 \mathrm{mM}$, respectively. Fractions with high acetate kinase activity were pooled and applied to affinity chromatography on Procion Blue HE-3B. The enzyme was eluted with ATP and no butyrate kinase activity was detected in the pooled fractions. After column chromatography on hydroxylapatite the acetate kinase seemed to be homogeneous as only one protein band was observed in denaturing polyacrylamide gels (Fig. 2). The yield of the purified enzyme was low $(15 \%)$, but it had a high specific activity of $1087 \mathrm{U} \mathrm{mg}^{-1}$.

The enzyme subunits had a relative molecular mass of $43 \mathrm{kDa}$ according to the results of the denaturing gel electrophoresis (Fig. 2). This value is in excellent 
Table 1. Purification of the acetate kinase from C. acetobutylicum DSM 1731

Activity was measured in the direction of acetyl phosphate formation using the coupled enzymic assay. Crude extracts contained butyrate kinase activities of about $8 \cdot 2 \mathrm{U} \mathrm{mg}^{-1}$.

\begin{tabular}{|lccccc|}
\hline Step & $\begin{array}{c}\text { Total } \\
\text { protein } \\
(\mathbf{m g})\end{array}$ & $\begin{array}{c}\text { Total } \\
\text { activity } \\
(\mathbf{U})\end{array}$ & $\begin{array}{c}\text { Specific } \\
\text { activity } \\
\left(\mathbf{U ~ m g ~}^{-1}\right)\end{array}$ & $\begin{array}{c}\text { Recovery } \\
(\%)\end{array}$ & $\begin{array}{c}\text { Purification } \\
\text { (fold) }\end{array}$ \\
\hline $\begin{array}{l}\text { Crude extract } \\
\begin{array}{l}\text { Anion-exchange chromatography } \\
\text { (Q-Sepharose FastFlow) }\end{array}\end{array}$ & $\begin{array}{c}580 \\
\text { Affinity chromatography }\end{array}$ & 2136 & $3 \cdot 7$ & 100 & 1 \\
$\begin{array}{l}\text { (Procion Blue HE-3B) } \\
\text { Hydroxylapatite chromatography }\end{array}$ & 0.41 & 401 & 980 & 19 & 265 \\
\hline
\end{tabular}

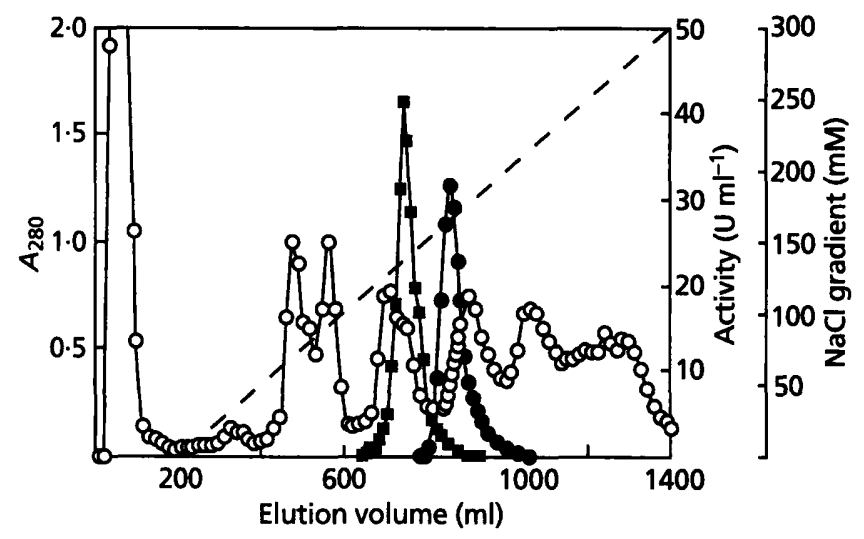

Fig. 1. Anion-exchange chromatography of crude extract from C. acetobutylicum DSM 1731 on Q-Sepharose FastFlow. The proteins were eluted by a linear gradient of increasing $\mathrm{NaCl}$ concentration and a flow rate of $1 \mathrm{ml} \mathrm{min}^{-1}$. 0 , Absorption (280 nm, 1:4 diluted); ---, NaCl gradient; 0 , acetate kinase activity $\left(\mathrm{U} \mathrm{m}^{-1}\right) ; \boldsymbol{Q}$, butyrate kinase activity $\left(\mathrm{U} \mathrm{ml}^{-1}\right)$.

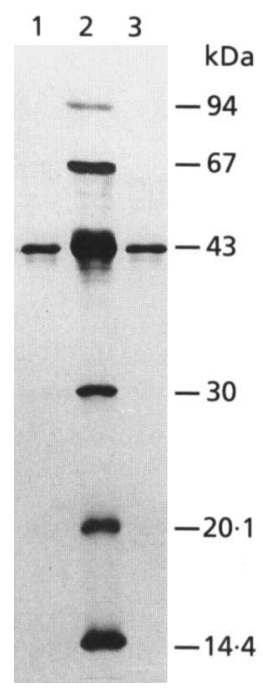

Fig. 2. Denaturing polyacrylamide gel of the purified acetate kinase from $C$. acetobutylicum. Lanes: 1 and 3, silver stain of the purified enzyme ( $1 \mu \mathrm{g}) ; 2$, size marker.

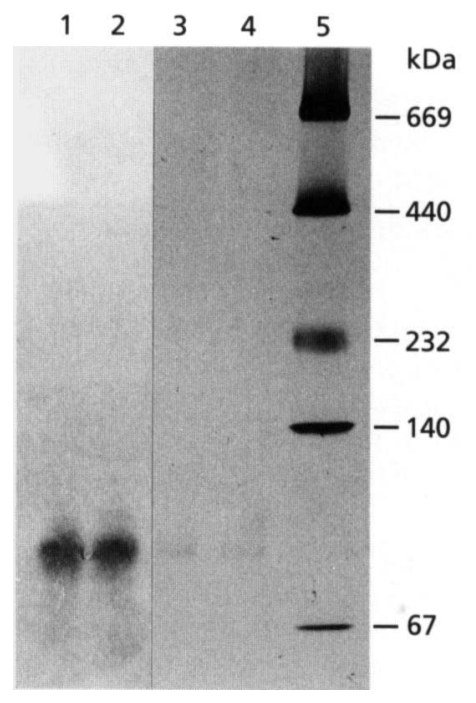

Fig. 3. Native polyacrylamide gel of the acetate kinase from C. acetobutylicum and detection of activity. Lanes: 1 and 2, activity stain of the purified enzyme; 3 and 4, silver stain of the purified enzyme $(10 \mu \mathrm{g}) ; 5$, size marker.

agreement with the calculated molecular mass of $44.3 \mathrm{kDa}$ of the ack gene, recently cloned from strain ATCC 824 (Boynton et al., 1996). It is also about the same as reported for the enzymes of Bacillus stearothermophilus (43 $\mathrm{kDa}$; Nakajima et al., 1978) and Veillonella alcalescens $(42 \mathrm{kDa}$; Griffith \& Nishimura, 1979), whereas a slightly lower value of $39 \mathrm{kDa}$ has been determined for the butyrate kinase of C. acetobutylicum (Hartmanis, 1987), which catalyses an analogous reaction.

The molecular mass of the native acetate kinase of $C$. acetobutylicum was determined by native gel electrophoresis and gel filtration using buffers with different ionic strength and a Superose 12 column. In silverstained native polyacrylamide gels only a faint band was visible corresponding to a molecular mass of $89 \mathrm{kDa}$ (Fig. 3) even after loading up to $10 \mu \mathrm{g}$ purified protein. This band represented native or at least renatured acetate kinase, as was shown by activity staining of the 
Table 2. Substrate specificity of the acetate kinase from C. acetobutylicum DSM 1731

\begin{tabular}{|lcc|}
\hline Substrates & $\begin{array}{c}\text { Concentration } \\
(\mathrm{mM})\end{array}$ & $\begin{array}{c}\text { Activity* } \\
(\%)\end{array}$ \\
\hline Formate & 250 & 0 \\
Acetate & 250 & 100 \\
Propionate & 250 & $2 \cdot 3$ \\
Butyrate & 250 & 0 \\
ATP & 5 & 100 \\
CTP & 5 & 36 \\
GTP & 5 & $2 \cdot 4$ \\
ITP & 5 & $4 \cdot 5$ \\
UTP & 5 & 10 \\
Mg & 10 & 100 \\
$\mathrm{Mn}^{2+}$ & 10 & 147 \\
$\mathrm{Ca}^{2+}$ & 10 & $1 \cdot 5$ \\
$\mathrm{Co}^{2+}$ & 10 & 53 \\
$\mathrm{Zn}^{2+}$ & 10 & 0 \\
\hline
\end{tabular}

* Activity was determined using the hydroxamate assay and replacing the standard components by the indicated substrates. Reactions were started by addition of $0.46 \mu \mathrm{g}$ acetate kinase. Activity with acetate, ATP and $\mathrm{Mg}^{2+}$ as substrate was $1078 \mathrm{U}$ $\mathrm{mg}^{-1}(100 \%)$.

gels preceding the silver stain (see below). Gel filtration experiments in the presence and absence of $200 \mathrm{mM}$ $\mathrm{NaCl}$ gave values of 94 and $87 \mathrm{kDa}$, respectively. These results suggest a dimeric form of the native enzyme. Native acetate kinases from various organisms also form oligomers (Aceti \& Ferry, 1988; Griffith \& Nishimura, 1979; Kahane \& Muhlrad, 1979; Nakajima et al., 1978). Monomer/dimer and dimer/tetramer systems, depending on the ionic strength, have been described for the enzymes of Acholeplasma laidlawii (Kahane \& Muhlrad, 1979) and Acetobacterium woodii (Winzer, 1992), respectively, and an associating monomer/dimer system has been suggested for the acetate kinase of E. coli (Fox \& Roseman, 1986). However, the gel filtration experiments in the presence and absence of $200 \mathrm{mM} \mathrm{NaCl}$ confirmed the dimeric structure of the C. acetobutylicum enzyme.

An activity stain specific for acetate kinase after separation by electrophoresis in native polyacrylamide gels was developed to examine the exact position of the native enzyme. The test system was based on the reduction by $\mathrm{NADPH}+\mathrm{H}^{+}$of NBT via PMS. $\mathrm{NADPH}+\mathrm{H}^{+}$was produced by coupling acetate kinase with hexokinase and glucose-6-phosphate dehydrogenase reactions as described for the coupled enzymic assay. Enzymic activity after electrophoresis was detected with enzymes from various organisms including E. coli (enzyme preparation of Boehringer Mannheim) and Acetobacterium woodii (crude extracts and purified enzyme; Winzer, 1992).

The substrate specificity was determined in the direction of acetyl formation using the coupled enzymic assay (acids) and the hydroxamate assay (acids, nucleoside triphosphates and divalent cations; Table 2). The enzyme was highly active with acetate, whereas the reaction rate with propionate was extremely low. No phosphorylation could be observed with formate and butyrate. Both test systems gave the same results. The acetate kinase also clearly preferred ATP as the phosphate donor. In contrast, the butyrate kinase of $C$. acetobutylicum catalyses an analogous reaction, but is also active with valerate, isobutyrate, propionate and other carboxylic acids (Hartmanis, 1987).

Under the conditions tested, acetate kinase showed highest activity in the presence of $\mathrm{Mn}^{2+}$, whereas with $\mathrm{Mg}^{2+}$ or $\mathrm{Co}^{2+}$ it was less efficient. Variation of the $\mathrm{MnCl}_{2}$ concentration with a constant concentration of ATP $(5 \mathrm{mM})$ gave maximal activity at a $\mathrm{Mn}^{2+} /$ ATP ratio of 1.5 (Fig. 4), suggesting that divalent cations were only necessary to complex with nucleotides without having further functions for the stability or catalytic activity of the enzyme. Similar results have been obtained for the acetate kinases of Methanothrix thermophila and A. laidlawii, whereas contradictory data have been reported for the E. coli enzyme (Anthony \& Spector, 1971; Fox \& Roseman, 1986). All other acetate kinases studied so far show also highest activities with $\mathrm{Mg}^{2+}$ or $\mathrm{Mn}^{2+}$ (Brown \& Akagi, 1966; Fox \& Roseman, 1986; Kahane \& Muhlrad, 1979; Nakajima et al., 1978; Rose et al., 1954; Yoshimura, 1978). In the absence of divalent cations no activity of the clostridial acetate kinase could be observed, as solely cationnucleotide complexes function as substrates in phosphotransferase reactions (Morrison, 1979).

The enzyme was inactivated by some reagents specific for thiol groups. Mercury compounds such as $\mathrm{HgCl}_{2}$ and $p$-hydroxymercuribenzoate were efficient inhibitors (remaining enzyme activity of 3 and $29 \%$, respectively, in the presence of $2.5 \mu \mathrm{M}$ inhibitor compared to a hydroxamate assay without these compounds), whereas iodoacetamide had no influence under the conditions tested $(97 \%$ of the control activity when $3.5 \mathrm{mM}$ substance was added). Acetate kinases of other organisms show a similar behaviour. In E. coli, $\mathrm{Hg}^{2+}$ sensitivity is probably due to modifications in the acetate/acetyl phosphate region of the catalytic site, since the overall reaction and the acetate-acetyl phosphate exchange is inhibited at the same degree, whereas the ADP-ATP exchange is entirely unaffected (Anthony \& Spector, 1971, 1972). Interestingly, mercury compounds have no effect on the butyrate kinase of $C$. acetobutylicum even in high concentrations (Hartmanis, 1987), possibly resulting from differences in the substrate-binding region of acetate and butyrate kinase for carboxylic acids.

The coupled enzymic assays were used to determine the reaction rates which gave hyperbolic saturation curves for the substrates of both directions (data not shown). The apparent $K_{\mathrm{m}}$ values were calculated from double reciprocal plots of the substrate concentrations versus the enzymic activities: $\mathrm{Mg}$-ATP $0.37 \mathrm{mM}$, acetate $73 \mathrm{mM}, \mathrm{Mg}$-ADP $0.71 \mathrm{mM}$ and acetyl phosphate $0.58 \mathrm{mM}$. 


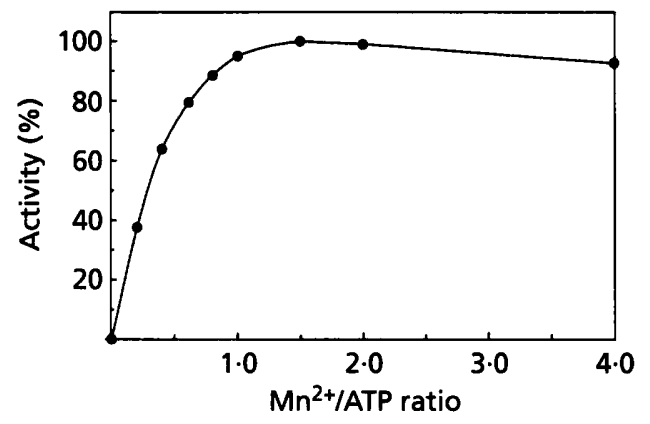

Fig. 4. Effect of the $\mathrm{Mn}^{2+}$ concentration on the activity of the acetate kinase from $C$. acetobutylicum. Activity was determined using the hydroxamate assay with a constant ATP concentration of $5 \mathrm{mM}$. Various amounts of $\mathrm{MnCl}_{2}$ were added resulting in the indicated $\mathrm{Mn}^{2+} / \mathrm{ATP}$ ratios. The reactions were started with $0.46 \mu \mathrm{g}$ purified enzyme. Maximal activity (100\%) was $1065 \mathrm{U}$ $\mathrm{mg}^{-1}$.

\section{Regulation}

During the shift from acid to solvent production $C$. acetobutylicum takes up the previously produced acids to form mainly acetone and butanol. Nevertheless, reduced activities of enzymes representing the acidproducing pathways are still present (Andersch et al., 1983; Hartmanis \& Gatenbeck, 1984) and some acetic and butyric acid is still formed in continuous cultures during solventogenesis (Jones \& Woods, 1986). Northern blot analysis was performed to determine the relative transcription levels of acetate-kinase-specific mRNA isolated from acid- and solvent-producing cells. A PCR fragment specific for the acetate kinase gene $(a c k)$ was used as a probe in this experiment. An alignment of the deduced amino acid sequences of acetate kinases from $E$. coli (Matsuyama et al., 1989), Bacillus subtilis (Grundy et al., 1993) and Methanosarcina thermophila (Latimer \& Ferry, 1993) revealed the existence of conserved regions which were used for construction of the degenerated oligonucleotides AK1, AK2 and AK3. PCR amplifications using these oligonucleotides and chromosomal DNA of C. acetobutylicum DSM 792 resulted in DNA fragments of about 750 (primer pair AK1/AK2) and $200 \mathrm{bp}$ (primer pair AK1/AK3). The fragment size was in agreement with the distance of the conserved regions in the acetate kinase genes mentioned above. The $750 \mathrm{bp}$ fragment was digested with $A l u \mathrm{I}$ and one of the resulting subfragments could be cloned in HincIIdigested pUC18. The nucleotide sequence of the 246-bp insert of the resulting recombinant plasmid pAK12 represented part of an open reading frame and its deduced amino acid sequence exhibited high homology (66-50\% identity and $83-68 \%$ similarity) to the acetate kinases of the organisms mentioned above and ORFX from E. coli (Schweizer \& Datta, 1991), but no significant homology to the butyrate kinases of C. acetobutylicum ATCC 824 (Walter et al., 1993) and a Clostridium beijerinckii strain (Oultram et al., 1993; formerly C. acetobutylicum NCIMB 8052 - Wilkinson et al., 1995). A recent report described cloning and

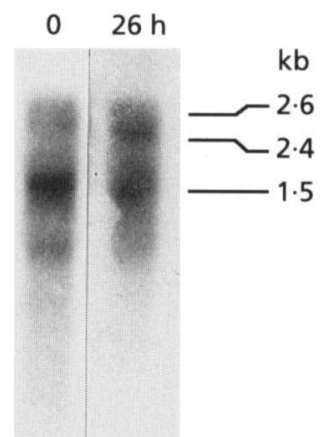

Fig. 5. Northern blot hybridizations using the radiolabelled insert of pAK12. Each lane contained $10 \mu \mathrm{g}$ total RNA from $C$. acetobutylicum DSM 1731, isolated from cells which were grown in continuous culture. Samples were taken before $(0 \mathrm{~h}=$ acid-producing cells) and $26 \mathrm{~h}$ after turning off the $\mathrm{pH}$ control (solvent-producing cells). Fragment sizes, as judged from comparison with size markers, are indicated on the right.

sequencing of the acetate kinase gene of C. acetobutylicum ATCC 824 (Boynton et al., 1996), confirming that the 246 bp fragment was indeed part of the ack gene (nt 1786-2032). Except for a substitution of T for C at position 1836 (resulting in a leucine instead of a proline in the gene product), the sequence from strain DSM 792 proved to be identical to that of strain ATCC 824 .

Southern blot analysis using the radiolabelled insert of pAK12 and digested chromosomal DNA of C. acetobutylicum DSM 792 resulted in an unambiguous signal pattern. Only one strong signal was visible with DNA digested by various restriction enzymes (possible exception $S s p$ I), and no nonspecific background hybridization could be observed (data not shown), indicating the lack of related sequences in the genome.

Acid-producing cells of C. acetobutylicum DSM 1731 were grown in continuous culture at $\mathrm{pH} 6.3$. The supernatant of the culture mainly contained acetic and butyric acid (about 50 and $28 \mathrm{mM}$, respectively), whereas no acetone and only small amounts of butanol $(3-4 \mathrm{mM})$ were formed. Solvent formation was induced by turning off the $\mathrm{pH}$ control. The $\mathrm{pH}$ decreased and at a value of 4.3 the control was turned on again. Twenty-six hours after induction of solventogenesis the concentrations of butanol $(15 \mathrm{mM})$ and acetone $(6 \mathrm{mM})$ still increased, whereas acetic and butyric acid had entered a constant level of about 12 and $15 \mathrm{mM}$, respectively. RNA was isolated from cells harvested at that time and from acidproducing cells. Fig. 5 shows the results of Northern blot analysis using the ack-specific probe. No sharp bands could be obtained with this probe, but the signals at $2 \cdot 6$, 2.4 and $1.5 \mathrm{~kb}$ represent transcripts of sizes that possibly correspond to a polycistronic message encoding phosphotransacetylase, acetate kinase and a single ack mRNA, respectively (Boynton et al., 1996). As the same blot gave strong and sharp signals lacking any background with probes specific for the thiolase A and B genes of the same organism (data not shown), the diffused banding was not due to damaged mRNA 
preparations. In strain ATCC 824, genes encoding phosphotransacetylase ( $p t a)$ and acetate kinase $(a c k)$ are adjacent on the chromosome, with pta upstream (Boynton et al., 1996). A single transcriptional start site has been mapped 70 bp upstream of the pta start codon. The lack of a transcriptional start site between the end of ack and the downstream following orf $X$ indicates a polycistronic arrangement of pta and ack (Boynton et al., 1996). This is in agreement with the mRNA sizes of $2.4-2.6 \mathrm{~kb}$ determined in this study. A polycistronic organization has also been suggested for the respective genes of E. coli and M. thermophila (Latimer \& Ferry 1993; Matsuyama et al., 1994; Singh-Wissmann \& Ferry, 1995) as well as the butyrate kinase and phosphotransbutyrylase genes of C. acetobutylicum ATCC 824 (Walter et al., 1993) and strain NCIMB 8052 (Oultram et al., 1993; now recognized as a C. beijerinckii strain - Wilkinson et al., 1995), whereas the acetate kinase gene of $B$. subtilis appears to be monocistronically organized (Grundy et al., 1993). In M. thermophila, the polycistronic transcript seems to be processed and the resulting additional transcript of $1.4 \mathrm{~kb}$ probably encodes the acetate kinase gene (Singh-Wissmann \& Ferry, 1995). A transcript of similar size $(1.5 \mathrm{~kb})$ has been observed in Northern blot hybridizations with the ack-specific probe of C. acetobutylicum (Fig. 5). As transcripts of different size can be formed by transcription from different promoters or by processing of a precursor, additional experiments are necessary to analyse the observed signal pattern. Processing or rapid degradation of the transcripts could also explain the diffused signals.

When C. acetobutylicum has shifted to solvent production, the specific activities in cell extracts of the terminal enzymes in the acid-producing pathways have been reported to be significantly reduced (Andersch $e t$ al., 1983; Hartmanis \& Gatenbeck, 1984). Nevertheless, some acetate and butyrate is still formed in solventproducing continuous cultures (Jones $\&$ Woods, 1986). A continued, but reduced transcription of the respective genes would therefore be expected. However, Northern blot analysis of RNA from acid- and solvent-producing cultures revealed no significant difference in the signal intensities, indicating a comparable transcription level. It has been suggested by Hüsemann \& Papoutsakis (1989) that butyrate kinase and phosphotransbutyrylase might be involved in butyrate reactivation by solventproducing cells. Possibly, this is also true for the acetate reactivation by acetate kinase and phosphotransacetylase.

\section{ACKNOWLEDGEMENTS}

This work was supported by a grant from the Deutsche Forschungsgemeinschaft.

\section{REFERENCES}

Aceti, D. J. \& Ferry, J. G. (1988). Purification and characterization of acetate kinase from acetate-grown Methanosarcina thermophila. J Biol Chem 263, 15444-15448.

Andersch, W., Bahl, H. \& Gottschalk, G. (1983). Level of enzymes involved in acetate, butyrate, acetone and butanol formation by Clostridium acetobutylicum. Eur J Appl Microbiol Biotechnol 18, 327-332.

Anthony, R. S. \& Spector, L. B. (1971). Exchange reactions catalyzed by acetate kinase. J Biol Chem 246, 6129-6135.

Anthony, R. S. \& Spector, L. B. (1972). Phosphorylated acetate kinase. J Biol Chem 247, 2120-2125.

Bahl, H., Andersch, W. \& Gottschalk, G. (1982). Continuous production of acetone and butanol by Clostridium acetobutylicum in a two-stage phosphate limited chemostat. Eur J Appl Microbiol Biotechnol 15, 201-205 (erratum 17, p. 73, 1983).

Bertram, J. \& Durre, P. (1989). Conjugal transfer and expression of streptococcal transposons in Clostridium acetobutylicum. Arch Microbiol 151, 551-557.

Blum, H., Beier, H. \& Gross, H. J. (1987). Improved silver staining of plant proteins, RNA and DNA in polyacrylamide gels. Electrophoresis 8, 93-99.

Boynton, Z. L., Bennett, G. N. \& Rudolph, F. B. (1996). Cloning, sequencing, and expression of genes encoding phosphotransacetylase and acetate kinase from Clostridium acetobutylicum ATCC 824. Appl Environ Microbiol 62, 2758-2766.

Bradford, M. M. (1976). A rapid and sensitive method for the quantitation of microgram quantities of protein utilizing the principle of protein-dye binding. Anal Biochem 72, 248-254.

Brown, M. S. \& Akagi, J. M. (1966). Purification of acetokinase from Desulfovibrio desulfuricans. J Bacteriol 92, 1273-1274.

Devereux, J., Haeberli, P. \& Smithies, O. (1984). A comprehensive set of sequence analysis programs for the VAX. Nucleic Acids Res $12,387-395$.

Durre, P. \& Bahl, H. (1996). Microbial production of acetone/ butanol/isopropanol. In Biotechnology, 2nd edn, vol. 6, pp. 229-268. Edited by M. Röhr. Weinheim: VCH.

Fox, D. K. \& Roseman, S. (1986). Isolation and characterization of homogeneous acetate kinase from Salmonella typhimurium and Escherichia coli. J Biol Chem 261, 13487-13497.

Gerischer, U. \& Durre, P. (1992). mRNA analysis of the adc gene region of Clostridium acetobutylicum during the shift to solventogenesis. J Bacteriol 174, 426-433.

Griffith, M. J. \& Nishimura, J. S. (1979). Acetate kinase from Veillonella alcalescens. $J$ Biol Chem 254, 442-446.

Grundy, F. J., Waters, D. A., Allen, S. H. G. \& Henkin, T. M. (1993). Regulation of the Bacillus subtilis acetate kinase gene by CcpA. $J$ Bacteriol 175, 7348-7355.

Hartmanis, M. G. N. (1987). Butyrate kinase from Clostridium acetobutylicum. J Biol Chem 262, 617-621.

Hartmanis, M. G. N. \& Gatenbeck, S. (1984). Intermediary metabolism in Clostridium acetobutylicum: levels of enzymes involved in the formation of acetate and butyrate. Appl Environ Microbiol 47, 1277-1283.

Hartmanis, M. G. N., Klason, T. \& Gatenbeck, S. (1984). Uptake and activation of acetate and butyrate in Clostridium acetobutylicum. Appl Microbiol Biotechnol 20, 66-71.

Hüsemann, M. H. W. \& Papoutsakis, E. T. (1989). Comparison between in vivo and in vitro enzyme activities in continuous and batch fermentations of Clostridium acetobutylicum. Appl Microbiol Biotechnol 30, 585-595.

Jones, D. T. \& Woods, D. R. (1986). Acetone-butanol fermentation revisited. Microbiol Rev 50, 484-524.

Kahane, I. \& Muhlrad, A. (1979). Purification and properties of acetate kinase from Acholeplasma laidlawii. J Bacteriol 137, 764-772. 
Laemmli, U. K. (1970). Cleavage of structural proteins during the assembly of the head of bacteriophage T4. Nature 227, 680-685.

Latimer, M. T. \& Ferry, J. G. (1993). Cloning, sequence analysis, and hyperexpression of the genes encoding phosphotransacetylase and acetate kinase from Methanosarcina thermophila. J Bacteriol 175, 6822-6829.

Marck, C. (1988). 'DNA Strider': a 'C' program for the fast analysis of DNA and protein sequences on the Apple Macintosh family of computers. Nucleic Acids Res 16, 1829-1836.

Marmur, J. (1960). A procedure for the isolation of deoxyribonucleic acid from microorganisms. J Mol Biol 3, 208-218.

Matsuyama, A., Yamamoto, H. \& Nakano, E. (1989). Cloning, expression, and nucleotide sequence of the Escherichia coli K-12 ack A gene. J Bacteriol 171, 577-580.

Matsuyama, A., Yamamoto-Otake, H., Hewitt, J., MacGillivray, R. T. A. \& Nakano, E. (1994). Nucleotide sequence of the phosphotransacetylase gene of Escherichia coli strain K12. Biochim Biophys Acta 1219, 559-562.

Morrison, J. F. (1979). Approaches to kinetic studies on metalactivated enzymes. Methods Enzymol 63, 257-294.

Nakajima, H., Suzuki, K. \& Imahori, K. (1978). Purification and properties of acetate kinase from Bacillus stearothermophilus. $J$ Biochem 84, 193-203.

O'Brien, R. W. \& Morris, J. G. (1971). Oxygen and the growth and metabolism of Clostridium acetobutylicum. J Gen Microbiol 68, 307-318.

Oelmuller, U., Kruger, N., Steinbuchel, A. \& Friedrich, C. (1990). Isolation of prokaryotic RNA and detection of specific mRNA with biotinylated probes. J Microbiol Methods 11, 73-81.

Oultram, J. D., Burr, I. D., Elmore, M. J. \& Minton, N. P. (1993). Cloning and sequence analysis of the genes encoding phosphotransbutyrylase and butyrate kinase from Clostridium acetobutylicum NCIMB 8052. Gene 131, 107-112.

Rose, I. A., Grunberg-Manago, M., Korey, R. S. \& Ochoa, S. (1954). Enzymatic phosphorylation of acetate. J Biol Chem 211, 737-756.
Sambrook, J., Fritsch, E. F. \& Maniatis, T. (1989). Molecular Cloning: a Laboratory Manual, 2nd edn. Cold Spring Harbor, NY: Cold Spring Harbor Laboratory.

Schweizer, H. P. \& Datta, P. (1991). The complete nucleotide sequence of the $t d c$ region of Escherichia coli. Nucleic Acids Res 17, 3994.

Singh-Wissmann, K. \& Ferry, J. G. (1995). Transcriptional regulation of the phosphotransacetylase-encoding and acetateencoding genes ( $p t a$ and $a c k$ ) from Methanosarcina thermophila. J Bacteriol 177, 1699-1702.

Walter, K. A., Nair, R. V., Cary, J. W., Bennett, G. N. \& Papoutsakis, E. T. (1993). Sequence and arrangement of two genes of the butyrate-synthesis pathway of Clostridium acetobutylicum ATCC 824. Gene 134, 107-111.

Wiesenborn, D. P., Rudolph, F. B. \& Papoutsakis, E. T. (1989). Phosphotransbutyrylase from Clostridium acetobutylicum ATCC 824 and its role in acidogenesis. Appl Environ Microbiol 55, 317-322.

Wilkinson, S. R., Young, M., Goodacre, R., Morris, J. G., Farrow, J. A. E. \& Collins, M.D. (1995). Phenotypic and genotypic differences between certain strains of Clostridium acetobutylicum. FEMS Microbiol Lett 125, 199-204.

Winzer, K. (1992). Reinigung und Charakterisierung der AcetatKinase aus Acetobacterium woodii. Diploma thesis, University of Göttingen.

Yanisch-Perron, C., Vieira, J. \& Messing, J. (1985). Improved M13 phage cloning vectors and host strains: nucleotide sequences of the M13mp18 and pUC19 vectors. Gene 33, 103-119.

Yoshimura, F. (1978). Purification and characterization of acetate kinase from Veillonella alcalescens ATCC 17748. Arch Biochem Biophys 189, 424-432.

Received 14 March 1997; revised 15 June 1997; accepted 19 June 1997. 